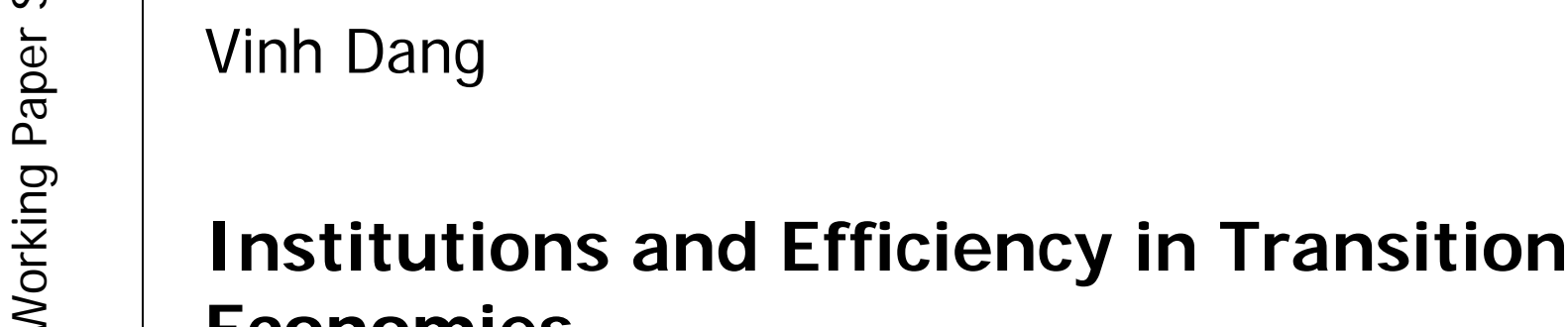
Economies

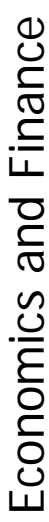

http://www.brunel.ac.uk/about/acad/sss/depts/economics 


\title{
INSTITUTIONS AND EFFICIENCY IN TRANSITION ECONOMIES
}

\author{
Vinh Dang* \\ PhD student \\ Department of Economics and Finance \\ School of Social Sciences, Brunel University \\ Kingston Lane, Uxbridge, Middlesex, UB10 0AH, UK
}

\begin{abstract}
This paper analyzes the effects of political and economic institutions on efficiency of transition economies over the 1995-2005 period. Perpetual Inventory Method is used to construct capital series for these countries, and then stochastic production frontier analysis is used to estimate the efficiency scores and effects of institutions at the same time. The empirical results show that better institutions are associated with higher efficiency. However, all else equal, the transition countries in East Asia are more efficient than Central and Eastern European or Former Soviet Union transition countries.
\end{abstract}

Keywords: institutions, efficiency, transition economies, stochastic frontier analysis JEL: O57, P26

\footnotetext{
* Tel: +44 1895265490

Fax: +44 1895269786

Email: vinh.dang@brunel.ac.uk
} 


\section{Introduction}

The significant role of institutions in determining growth has been confirmed in many studies. Barro (1991) shows that growth rate is positively associated with political stability and inversely related to a proxy ${ }^{1}$ of market distortions. Mauro (1995) concludes that bureaucratic efficiency causes high investment and growth. Rodrik's (2000) study on 90 countries over 1970-1989 leads to a conclusion that the more democratic a country is the smaller the variance of its long run growth. In addition, the effect of institutions on growth is not just to promote capital accumulation as Knack and Keefer (1995) reveal that it is still significant after controlling for factor accumulation and policy. This suggests that institutions should be an important determinant of productivity and efficiency.

The purpose of this paper is to investigate the effect of institutions on efficiency in the context of transition economies. Since the fall of the socialist system, former socialist countries have undergone a transformation process from a centrally planned economy to a market-based economic system. We have observed marked difference in economic performance of these economies. In Eastern Europe and Central Asia, almost all of transition countries experienced sharp output fall in the early 1990s and then went through a recovery process with positive growth rates. At the same time in East Asia China, Vietnam and Cambodia managed to grow at high and steady rates.

While factor accumulation certainly plays an important part in explaining growth, differences in efficiency also matter, especially when a lot of "creative destruction" is taking place. For many transition countries the problem is more about utilizing existing factors efficiently than about accumulating them. We can say that they have been operating below the production possibility frontier (PPF) and it will take them a while to get to the level of efficiency attained in advanced economies. Moreover, due to differences in initial conditions, the speed of transition and socio-economic settings, we can expect large variation in efficiency level of these countries.

During the transition process, different institutional settings, both political and economic, have emerged in these countries. As noted in Murrell (2003), institutional quality in transition economies in general has improved quickly. However, there is a huge divergence in the levels of institutional development. Kaufmann et al. (2005) show that countries like Czech Republic, Slovakia and Poland have institutional quality that is in many aspects

\footnotetext{
${ }^{1}$ The deviation from the sample mean of the purchasing power parity for investment in 1960 .
} 
comparable to those of developed countries while other countries continue to lag far behind. Therefore, the experience of transition countries in terms of recovering from a disrupted system and building necessary institutions for a market economy can be viewed as something close to a natural experiment for analyzing the effect of institutions on growth in general and improvement in efficiency in particular.

Theoretically, there are many channels through which institutions can affect economic growth and efficiency. Democratic regimes with check and balance mechanisms are better able to curb corruption and prevent misuse of productive resources, especially in investment activities involving public funds, which is good for growth and efficiency. Sandholtz and Koetzle (2000) find that corruption is lower when democratic norms and institutions are stronger. In an effort to explain corruption Treisman (2000) also concludes that democracy reduces corruption though it is well established democracy rather than recent democratization process that matters (Sung (2004) also comes to similar conclusion). Good institutions can encourage accumulation of physical capital, human capital and technological knowledge and these factors in turn help improve efficiency. Bevan et al. (2004) finds that development of legal institutions has positive effect on FDI inflows to transition countries in Europe, which is supposed to bring in more advanced technologies to local economies and help enhance their efficiency. In addition, economic freedom is found by Dawson (1998), among others, to affect growth directly via total factor productivity and indirectly through investment.

Though there have been many studies on the relationship between institutions and growth there are very few attempts to relate efficiency to institutions, especially in the transition context. Monorey and Lovell (1997) compare the efficiency of 17 Western European market economies and that of 7 Eastern European planned economies. With a dummy variable to identify planned economies, their research shows that over the period 1978-1980 the Eastern European planned economies were only about three fourths as efficient as the Western European market economies. Using a panel of more than 70 countries over the period 1975-1990, economic freedom measures compiled by James Gwartney, Robert Lawson and Walter Block and stochastic frontier analysis, Adkins et al. (2002) show that increase in economic freedom leads to higher efficiency. However, two measures of political freedom, namely civil liberties and political rights taken from the Freedom House Index, are not significant in their model. In an attempt to test the relationship between governance, as reported in Kaufmann et al. (1999), and technical efficiency, Meon and Weill (2005) find that for a sample of 62 countries in 1990 better governance, especially government efficiency, is associated with greater technical efficiency. 
To the best of our knowledge, there has not been any research that digs into the relationship between institution and efficiency in transition economies since the collapse of the Soviet Bloc. Perhaps it is because of the lack of data about institutions, capital and labour in these countries. One of the contributions of this paper is to estimate capital series for these countries from gross investment data using the Perpetual Inventory Method. Then, following Battese and Coelli (1995), stochastic frontier analysis is used to estimate the efficiency and effect of institutions on efficiency at the same time by maximum likelihood technique.

The next section presents an overview of the literature on stochastic frontier analysis and the specification of the production and efficiency functions. It will be followed by description of data in Section III and empirical results in Section IV. Section V will conclude the paper.

\section{The stochastic frontier analysis and the modelling of efficiency}

\section{Stochastic frontier model}

The stochastic frontier production function was independently developed by Aigner, Lovell and Schmidt (1977) and Meeusen and van den Broeck (1977). Many researchers have used the model to estimate technical inefficiency for comparing efficiencies of firms or economies. Technical efficiency is defined as the ratio of observed output over the maximum feasible output (the frontier) given the level of inputs. For a panel data analysis with $i$ as producer identifier and $t$ as time period, the technical efficiency is depicted as:

$$
T E_{i t}=\frac{y_{i t}}{f\left(x_{i t} ; \beta\right) \exp \left(v_{i t}\right)} ; T E_{i t} \leq 1
$$

In equation (1.1), $x_{i t}$ is a ( $\left.1 \mathrm{x} \mathrm{k}\right)$ vector of inputs, $\beta$ is a $(\mathrm{k} \mathrm{x} 1)$ vector of coefficients to be estimated; $v_{i t}$ are random errors that are assumed to be independently and identically distributed as $N\left(0, \sigma_{v}^{2}\right)$. The $v_{i t}$ is stochastic element of the production function that capture random shocks to each producer/country. So the production frontier model will look like:

$$
y_{i t}=f\left(x_{i t} ; \beta\right) \cdot \exp \left(v_{i t}\right) \cdot T E_{i t}
$$

Let $T E_{i t}=\exp \left(-u_{i t}\right)$ and assume that $f\left(x_{i t} ; \beta\right)$ takes the log-linear Cobb-Douglas form the stochastic production frontier model becomes

$$
\ln y_{i t}=\beta_{o}+\sum_{k} \beta_{k} \ln x_{k, i t}+v_{i t}-u_{i t}
$$


In equation (1.3) $\mathrm{u}_{\mathrm{it}}$ is the measure of inefficiency because the higher the $\mathrm{u}_{\mathrm{it}}$ the lower the $\mathrm{TE}_{\mathrm{it}}$. Equation (1.3) is a linear regression model with a composite error $\varepsilon_{i t}=v_{i t}-u_{i t}$ where $v_{i t}$ is the two-sided stochastic error and $u_{i t}$ is the nonnegative inefficiency term. Because $T E_{i t} \leq 1$ we have $\mathrm{u}_{\mathrm{it}} \geq 0$ and the composite error $\varepsilon_{i t}$ is asymmetric. Therefore, OLS estimation can not provide a consistent estimate of $\beta_{0}$. Moreover, OLS can not provide estimates of $u_{i t}$ which are central to efficiency analyses. In the standard efficiency literature, the frontier equation is estimated by maximum likelihood techniques with assumptions about distribution of $v_{i t}$ and $u_{i t}$ and $u_{i t}$ are extracted from the composite error.

Early attempts ${ }^{2}$ to explain efficiency effects adopt two-stage approach, in which efficiency scores are estimated in the first stage and then regressed against some explanatory variables in the second. However, the assumption of identical distribution of $u_{i t}$ in the first stage is violated in the second stage which is usually OLS estimation. Battese and Coelli (1995) propose a model for technical inefficiency effects in a stochastic frontier function for panel data. The stochastic frontier and the inefficiency functions are estimated simultaneously by maximum likelihood. The panel specification of the model is as follows:

$$
y_{i t}=x_{i t} \beta+v_{i t}-u_{i t}
$$

where with $\mathrm{i}=1, \ldots, \mathrm{N}$ and $\mathrm{t}=1, \ldots, \mathrm{T} ; y_{i t}$ is the logarithm of the output for country $\mathrm{i}$ in period $\mathrm{t}, x_{i t}$ is a vector of inputs (in $\log$ ), and $\beta$ is a vector of unknown parameters to be estimated. vit is assumed to be iid $\mathrm{N}(0, \sigma \mathrm{v} 2)$ random error and distributed independently of $u_{i t}$. Technical inefficiency $u_{i t}$ is a non-negative random variable assumed to be independently distributed such that $u_{i t}$ is obtained by truncation (at zero) of the normal distribution $N\left(z_{i t} \delta, \sigma_{u}^{2}\right)$. In another word, the technical inefficiency effect $\mathrm{u}_{\mathrm{it}}$ is modelled as:

$$
u_{i t}=z_{i t} \delta+w_{i t}
$$

where the random error $\mathrm{w}_{\mathrm{it}}$ is assumed to follow normal distribution $\mathrm{N}\left(0, \sigma^{2}\right)$ truncated at such a point that $u_{i t} \geq 0$; the $z_{i t}$ is a vector of explanatory variables associated with technical inefficiency and $\delta$ is a vector of unknown coefficients to be estimated.

The maximum likelihood estimation of the model's coefficients is facilitated by Battese and Corra (1977) parameterization, $\sigma^{2}=\sigma_{v}^{2}+\sigma_{u}^{2}$ and $\gamma=\sigma_{u}^{2} /\left(\sigma_{v}^{2}+\sigma_{u}^{2}\right)$ and they are estimated by the software Frontier 4.1 (Coelli, 1996). $\sigma^{2}$ is the sum of variances of the stochastic error and the inefficiency term and $\gamma$ is the ratio of variance of the inefficiency term over the total variance. If $\gamma$ is significant we can say that the inefficiency matters and we can model the inefficiency.

\footnotetext{
${ }^{2}$ Pitt and Lee (1981), Kalirajan and Shand (1986).
} 


\section{Specification of production function and modelling of efficiency}

In stochastic frontier analysis, specification of production function is important because efficiency is measured against an estimated frontier. If the frontier function is misspecified the conclusion about the dynamics or determination of efficiency may be wrong. The Cobb-Douglas production function is widely used in the literature on economic growth. However, there have been several studies which test the validity of the Cobb-Douglas specification. Based on a panel of 82 countries over a 28-year period, Duffy and Papageorgiou (2000) find that Cobb-Douglas can be rejected in favour of a more general CES specification. In theory, Cobb-Douglas is not as good as translog function since translog is a good first order approximation of many different types of functions with Cobb-Douglas as a special case. In another attempt to examine Cobb-Douglas specification with the presence of technical inefficiency with the same data set as the above, Kneller and Stevens (2003) also rejects Cobb-Douglas vis-à-vis the translog function.

In this paper, we will also estimate the production frontier with both translog and Cobb-Douglas technologies. The production frontier equations are:

(i) Cobb-Douglas: $y_{i t}=\beta_{0}+\beta_{1} k_{i t}+\beta_{2} l_{i t}+\beta_{3} t+v_{i t}-u_{i t}$

(ii) Translog: $y_{i t}=\beta_{0}+\beta_{1} k_{i t}+\beta_{2} l_{i t}+\beta_{3} k_{i t}{ }^{2}+\beta_{4} l_{i t}{ }^{2}+\beta_{5} k_{i t} l_{i t}+\beta_{6} t+v_{i t}-u_{i t}$

Here, $y_{i t}$ is the logarithm of output for country $i$ at time $\mathrm{t}, \mathrm{k}$ is the logarithm of capital stock and 1 is the logarithm of labour. The time trend $(t)$ is added to account for movement in the frontier (Kneller and Stevens, 2003).

To examine the effect of institutions on efficiency, the inefficiency term $u_{i t}$ is modelled as a function of the degree of economic freedom as proxied by the Index of Economic Freedom (IEF), which is developed by the Heritage Foundation, and levels of Political Rights (PR) and Civil Liberties (CL) published by the Freedom House. The average value of PR and CL is collectively called Freedom House Index (FHI) .To account for systematic changes of efficiency over time, a time trend is also added to efficiency effect model. Time trend has been found significant in some efficiency analyses (see Kneller and Stevens (2003) for example).

Svejnar (2002) observes that the Central and Eastern and European countries had smaller output declines and could reverse the decline earlier than the countries of the Commonwealth of Independent States. At the same time, Eastern Asian transition economies did not suffer from recession and have had high growth rates. It seems there are regional characteristics that should be picked up by regional dummies. Therefore, three dummies are 
generated and added to the efficiency model to account for potential region-specific effects for Central and Eastern Europe (CEE), Commonwealth of Independent States (CIS) and East Asia $(\mathrm{EA})^{3}$. In general, the technical efficiency function will look like this:

$$
u_{i t}=\delta_{0}+\delta_{1} I E F_{i t}+\delta_{2} F H I_{i t}+\delta_{3} R D_{i}+\delta_{4} t i m e+w_{i t}
$$

with $\mathrm{RD}_{\mathrm{i}}$ being either $\mathrm{CEE}$, CIS or EA, with CEE used as control group.

\section{Data}

This research uses a panel of 28 transition economies over the $1995-2005$ period. The selection of countries and time period is mainly on the basis of data availability. 1995 is the year when the Index of Economic Freedom data was first available. Two types of data that need detailing are input-output data and measures of institutions.

\section{Input-output data}

The growth and efficiency literature usually uses either the World Bank's STARS dataset $^{4}$ or Summer and Heston's dataset (Penn World Table). However, these datasets do not include all transition countries. So for the purpose of this research we use the World Bank Development Indicators (WBDIs) for output (GDP), gross investment and labour. Output is total GDP converted to 2000 constant US dollar at official exchange rate. The data on labour is the total labour force in the relevant countries.

Since capital stock data are not available for all countries in the sample in any existing databases, the transition countries' investment series (gross capital formation) are used to construct capital series by applying the Perpetual Inventory Method. According to the method, the capital stock evolves as follows:

$$
K_{t}=I_{t}+(1-\delta) K_{t-1},
$$

with $\delta$ being the depreciation rate of capital.

By rearranging (7) we obtain:

$$
K_{t-1}=\frac{I_{t}}{g+\delta},
$$

where $\mathrm{g}$ is the growth rate of the capital stock which is assumed to be equal the average of GDP growth rates over the estimation period.

\footnotetext{
${ }^{3}$ CIS countries include Armenia, Azerbaijan, Belarus, Estonia, Georgia, Kazakhstan, Kyrgyz Republic, Latvia, Lithuania.

${ }^{4}$ developed by two World Bank researchers V. Nehru and A. Dhareshwar (1993).
} 
Selecting the correct depreciation rate $\delta$ in calculating capital stocks is very important. If the rate is too high capital accumulation will be low and productivity growth will be overestimated and vice versa. In the growth literature one depreciation rate is often applied across the whole sample of countries, be they developed or developing countries $(4 \%$ in Nehru and Dhareshwar (1993) and 7\% in Easterly and Rebelo (1993)). However, depreciation rates applied to developed and developing countries should be different because investment projects in developing countries are normally not as efficient as those in developed countries. That is not to mention corruption which is more pronounced in developing countries than in developed ones. $\mathrm{Bu}$ (2006) estimates depreciation rates from firm level data of some developing countries and finds them to be much higher than rates used in the above-cited growth and efficiency analyses. Prichett (2000) reports that over half of developing countries in the sample under investigation have negative total factor productivity. One possible explanation could be the overvaluation of capital which is equivalent to low depreciation rate. Therefore, in this paper the capital series are generated with a depreciation rate $\delta=10 \%{ }^{5}$. Unfortunately, we unable to compare our capital series with existing ones because they are only available for pre-1990 periods ${ }^{6}$ but we do not have investment series for most of transition countries (all but China and Hungary) to estimate capital stock before 1990.

\section{Measures of institutions}

Many researchers of institutional economics use the Fraser Institute's Economic Freedom Index constructed by James D. Gwartney, Robert A. Lawson and J. R. Clark ${ }^{7}$. However, this dataset does not cover all transition countries ${ }^{8}$ and before 2000 it was only available for every five years. In this paper we use the Index of Economic Freedom data developed by the Heritage Foundation and the Wall Street Journal. The dataset starts from 1995 and is available for all transition countries. The authors of the Index collect 50 independent economic variables that are categorized into ten economic freedom factors (IFE factors): trade policy, fiscal burden or government, government intervention, monetary policy, capital flows and foreign investment, banking and finance, wages and prices, property rights, regulation and informal market. The difference between this data set and others is that the

\footnotetext{
${ }^{5}$ For robustness check $6 \%$ depreciation rate is also used to generate another capital series but the main estimation results do not change (see Table A.3).

${ }^{6}$ 1950-1988 in Penn World Table 5.6 (capital series not available in later version) and 1950-1990 in World Bank dataset.

${ }^{7}$ Gwartney et al., 1999.

8 only 21 transition countries (19 Central and Eastern European countries and two East Asian countries).
} 
values of the variables are calculated with data available from various sources ${ }^{9}$ which are less subject to subjective survey data. Each factor is graded from 1 to 5 , with a score of 1 representing an economic environment that is the most conducive to economic freedom. Table A.1 in the Appendix shows the correlation matrix of these ten factors. The Fraser Institute's Economic Freedom Index and the Heritage Foundation's Index of Economic Freedom are highly correlated with an coefficient of $0.8^{10}$.

So far, many institution researchers have used the composite indexes such as the index of governance published by Daniel Kaufmann and his co-authors, the Gwartney et al.'s Economic Freedom Index (Fraser Institute) or the Heritage Foundation's Index of Economic Freedom in their empirical researches but there have been doubts about their consistency and relevance. Berggren (2002) observes that the Gwartney et al.'s index has different components and is constructed with different weighting schemes from one year to another. Heckelman and Stroup (2005) suggest that empirical researchers should use individual economic freedom indicators instead of the aggregate indexes because misinterpretation may arise with regard to different types of economic freedom.

To avoid using the composite index we apply the Principal Component Analysis to the ten IEF factors and select some principal components as measures of economic freedom. This technique can help reduce the dimensionality of the original data while retaining the maximum variation of the underlying variables. The principal components, by construction, are independent of each other. The parallel analysis and the Velicer's minimum average partial correlation analysis for selecting number of components to be retained indicate that we should use two components. As a result, economic institutions in this paper will be represented by the first two principal components (COMP1 and COMP2).

Table A.2 in the Appendix is the loading matrix of the principal component analysis and the cumulative variance that is explained by variances of components. It tells about the importance of principal individual components how they are related to the underlying variables. The first component, which by construction has the highest variance, can be interpreted as a general measure of freedom. The variance of the first component explains $50.5 \%$ of the total variance of the 10 factors. The second component is positively correlated with fiscal policy, government intervention and monetary policy and negatively correlated with foreign investment, property rights and regulation. We can think of the second component as a contrast between macroeconomic policy and business-related policy. High scores on this component is associated with less freedom in terms of macroeconomic

\footnotetext{
${ }^{9}$ See Beach and Miles (2006) for details.

${ }^{10}$ Note that for the Fraser Institute's index, the higher the score the more freedom there is.
} 
environment and more freedom in the business environment. Between the first two components they explain $64.3 \%$ of the total variance of all factors.

As for political institutions two measures are widely used in the literature: civil liberties (CL) and political rights (PR). These measures are published by the Freedom House which uses surveys and assessment reports to evaluate the actual rights and freedoms enjoyed by individuals. PR and CL are scored from one to seven for each country in each year with larger number indicating less freedom. PR and CL are highly correlated (0.94) in this sample. In the actual estimations, a simple average index of them (FHI) is also used (estimations with PR and CL used separately are reported in the Annex - Table A.2).

Table 1: Summary statistics for 28 countries, 1995-2005

\begin{tabular}{lllll}
\hline Variable & Mean & Standard deviation & Minimum & Maximum \\
\hline $\mathrm{y}$ & 23.29174 & 1.647378 & 20.51851 & 28.26483 \\
$\mathrm{k}$ & 23.76579 & 1.759886 & 20.49101 & 29.02706 \\
$\mathrm{l}$ & 15.32429 & 1.507875 & 13.40378 & 20.46972 \\
$\mathrm{FHI}$ & 3.805195 & 1.977736 & 1 & 7 \\
$\mathrm{PR}$ & 3.75 & 2.264116 & 1 & 7 \\
$\mathrm{CL}$ & 3.86039 & 1.745162 & 1 & 7 \\
$\mathrm{COMP} 1$ & $-4.74 \mathrm{E}-09$ & 2.24695 & -5.68623 & 4.741608 \\
COMP2 & $5.13 \mathrm{E}-10$ & 1.176851 & -2.69015 & 2.418832 \\
\hline
\end{tabular}

Note: $\mathrm{y}, \mathrm{k}$ and $\mathrm{l}$ are logarithms of output, capital and labour; FHI is the simple average index of Political Rights (PR) and Civil Liberties (CL); COMP1 and COMP2 are the first two principal components of ten economic freedom factors

\section{Empirical results and discussions}

Both Translog and Cobb-Douglas production functions are estimated with the final efficiency model being:

$$
u_{i t}=\delta_{0}+\delta_{1} C O M P 1_{i t}+\delta_{2} C O M P 2_{i t}+\delta_{3} F H I_{i t}+\delta_{4} R D_{i}+\delta_{5} t i m e+\varepsilon_{i t}
$$

Regressions are run with one regional dummy separately and with CEE as control group but only the EA dummy is significant. PR, CL and the simple average of them (FHI) are used separately in the regressions but there are no qualitative changes. Changes in terms of coefficients' magnitude are not substantial. Table 2 presents the result with FHI as measure of political freedom, with and without and EA - dummy for East Asia (see Table A.2 for results with PR and CL). 
Table 2.

Estimation result with FHI

\begin{tabular}{|c|c|c|c|c|}
\hline & $\begin{array}{l}\text { Translog } \\
\text { without regional } \\
\text { dummy (1) }\end{array}$ & $\begin{array}{l}\text { Cobb-Douglas } \\
\text { without regional } \\
\text { dummy (2) }\end{array}$ & $\begin{array}{l}\text { Translog with EA } \\
\text { dummy (3) }\end{array}$ & $\begin{array}{l}\text { CD with EA } \\
\text { dummy (4) }\end{array}$ \\
\hline \multicolumn{5}{|l|}{ Production frontier } \\
\hline Constant & $9.23 * *(2.68)$ & $10.00 * * *(19.99)$ & $10.25 * *(3.58)$ & $10.58 * * *(21.69)$ \\
\hline $\mathrm{k}$ & $-0.46 *(-1.86)$ & $0.1 * * *(13.87)$ & $-0.65 * *(-3.01)$ & $0.09 * * *(12.18)$ \\
\hline 1 & $1.18^{* *}(4.51)$ & $0.76 * * *(24.24)$ & $1.35 * * *(8.4)$ & $0.73 * * *(22.86)$ \\
\hline k2 & $0.03 * * *(30.13)$ & - & $0.03 * * *(34.28)$ & - \\
\hline 12 & $-0.02(-1.22)$ & - & $-0.03 * *(-2.7)$ & - \\
\hline $\mathrm{kl}$ & $-0.01(-0.82)$ & - & $-0.001(-0.9)$ & - \\
\hline time & $-0.02 * *(-4.0)$ & $0.03 * *(2.92)$ & $-0.02 * * *(-5.12)$ & $0.03 * *(2.91)$ \\
\hline \multicolumn{5}{|l|}{ Efficiency effects } \\
\hline Constant & $-34.86 * * *(-40.6)$ & $-44.14 * * *(-15.01)$ & $-33.68 * * *(-26.59)$ & $-51.27 * * *(-20.67)$ \\
\hline COMP1 & $1.23 * * *(9.61)$ & $0.81 * *(4.89)$ & $0.82 * *(3.86)$ & $0.59 * *(2.43)$ \\
\hline COMP2 & $2.46^{* * *}(7.4)$ & $13.8 * *(3.2)$ & $1.48 * *(3.45)$ & $0.96 * *(2.33)$ \\
\hline FHI & $2.85 * * *(12.27)$ & $5.3^{* * *}(12.19)$ & $3.68 * * *(13.02)$ & $6.7 * * *(17.74)$ \\
\hline EA dummy & - & - & $-15.82 * * *(-12.77)$ & $-7.8 * * *(-6.57)$ \\
\hline time & $1.1 * * *(11.81)$ & $0.89 * * *(7.9)$ & $0.79 * * *(5.46)$ & $0.86 * * *(7.1)$ \\
\hline$\sigma^{2}$ & $13.64 * * *(24.13)$ & $19.41 * * *(10)$ & $11.57 * * *(11.64)$ & $25.12 * * *(10.66)$ \\
\hline$\gamma$ & $0.99 * * *(3423.1)$ & $0.99 * * *(402.11)$ & $0.99 * * *(3425.9)$ & $0.99 * * *(715.15)$ \\
\hline Log likelihood & -195.73 & -419.4 & -181.75 & -414.3 \\
\hline Likelihood ratio test & 845.86 & 425.4 & 873.82 & 435.6 \\
\hline
\end{tabular}

Note: t-ratio in parenthesis; *, ** and *** denote significance at the $10 \%, 5 \%$ and $1 \%$ levels.

In all specifications the likelihood ratio test results show that the coefficients of the efficiency equation and $\sigma^{2}$ and $\gamma$ are jointly significant. This means the specification of the model is correct. The significance of the variance parameters $\sigma^{2}$ (sum of variances) and $\gamma$ (variance of inefficiency term over sum of variances) indicates that technical efficiency does matter in the production function and that the stochastic specification is appropriate. With $\gamma$ being very close to one in all specifications we can say that variation in technical efficiency is substantial among transition economies.

In efficiency analysis, it is important to have good specification of the production function since different technologies will result in different measures of efficiency. As mentioned in Section II the Cobb-Douglas technology has been rejected in several tests. Here, following the same line, specification tests are also done by calculating generalized likelihood 
ratios and they show that translog models should be used in frontier and efficiency analyses for transition economies (the ratios are 447.4 and 465.2 for specification with and without EA dummy respectively).

The first important finding of this paper is the significance of economic and political freedoms in determining efficiency. In all the models presented in the Table 2, economic and political freedoms have positive and significant coefficients. Since $u_{i t}$ in equation (9) is inefficiency (or distance from the frontier) and higher values of economic and political freedoms means less freedom, the positive coefficients can be interpreted as implying that higher level of freedom is associated with higher level of efficiency.

Empirically, the effect of democracy on growth and efficiency has been controversial in the literature. Minier (1998) finds that countries that democratized early growth faster than others who did not choose a democratic path. Barro (1996) reports a hump-shaped relationship between democracy and growth. When trying to disentangle the effect of democracy on growth Tavares and Wacziarg (2001) concludes that, overall, the negative effect of democracy is larger than the positive one. In Adkins et al. (2002) the Political Rights and Civil Liberties are not significant. Here they do turn out to be significant both through the composite index and on their own (Table A.3), even after the economic freedom has been controlled for. This is consistent with the result found in Meon and Weill (2005) for a larger set of countries that the rule of law and control of corruption are associated with higher efficiency.

The second significant finding is that the coefficient of East Asia dummy is negative and significant. This means that East Asia's transition economies on average, ceteris paribus, are more efficient than the Eastern European and Former Soviet Union countries in the sample. This empirical result may look counter-intuitive for some people since many Eastern European countries (Czech Republic, Hungary and Poland for example) have rather advanced production base vis-à-vis the East Asian ones. However, this result can manifest the fact that the Eastern European transition economies underwent an initial period of "disorganization" when the old production system was destroyed almost overnight and a new one has not been in place ${ }^{11}$. It takes time to build new business links, to employ new technology and to adjust production methods to market signals, especially when market was fledgling. At the same time China, Vietnam and, to a lesser extent, Cambodia had been experimenting with market economy for a while before the beginning of the period under study. The interesting point is that East Asian transition countries manage to use more efficiently the resources they have

\footnotetext{
${ }^{11}$ Blanchard and Kremer (1997).
} 
though they have less production capacity than Central and Eastern European ones in this period.

Among the East Asian economies China was the first to reform and adopt market economy, though gradually. More importantly, China is a huge country and it has produced a remarkable growth rate since the beginning of its reform. Therefore there are reasons to believe that the East Asian effect is dominated by China and possibly only by China. To check if Cambodia and Vietnam also have the efficiency effect the model (3) in Table 2 is estimated again with a dummy for China and another one for Cambodia and Vietnam in the efficiency equation. The result is that are both significant (see Table A.4). Thus we can safely confirm that the three East Asian economies have higher efficiency than the other countries in the sample given the same level of production factors and institutions. All this said, it is worth mentioning that East Asian countries have less economic and political freedom on average (3.68 compared to 3.06 of CEE and 3.5 of FSU on aggregate EFI score; 6.39 compared with 2.15 and 4.38 on FHI).

\section{Conclusion}

The role of institutions in economic growth and efficiency has been discussed widely in the literature. Though empirical results change from one measure of institution to another, or from one dataset to another there seems to be a general conclusion that institutions do have positive effects on growth and efficiency. Since the collapse of the Soviet Bloc the experience of transition economies has provided something akin to a natural experiment to test the effect of institutions on efficiency. Applying stochastic frontier analysis technique, this paper has confirmed the positive effects of economic and political institutions as measured by the Index of Economic Freedom (Heritage Foundation) and the Freedom House Index respectively. For 28 transition economies over the period 1995-2005, more economic or political freedom is found to reduce the level of inefficiency. The empirical result for the effect of political freedom has been mixed but our paper shows that it does have significant role in improving efficiency, at least in the context of transition economies. Of course institutions do not solely determine efficiency but improvement of institutional quality should help transition economies to gain higher efficiency. The positive role of institutions found here is robust to different constructed measures of capital series (depreciation rates of $10 \%$ and $6 \%$ ).

Among these transition economies, the East Asian ones are, ceteris paribus, more efficient than others. Moreover, this effect is not wholly limited to China. This may be due to 
the famous dual approach to reform and liberalization that was first initiated by China and then followed by Vietnam and Cambodia when they moved away from planned economy.

Though the issue of causality between institution and efficiency is controversial and the results obtained here are subject to questions, hopefully this paper will contribute to clearer understanding of the role of institutions, both economic and political. 


\section{Annex}

Table A.1

Correlations of Indices of Economic Freedom (Heritage Foundation)

$\begin{array}{lllllllllll} & \text { Trade } & \text { Fiscal } & \text { Gov_int } & \text { Mon_pol } & \text { For_inv } & \text { Banking } & \text { WP } & \text { PROP } & \text { REG } & \text { INFMKT } \\ \text { Trade } & 1 & & & & & & & & & \\ \text { Fiscal } & 0.2402 & 1 & & & & & & & & \\ \text { Gov_int } & 0.4318 & 0.2383 & 1 & & & & & & & \\ \text { Mon_pol } & 0.1572 & 0.2839 & 0.377 & 1 & & & & & \\ \text { For_inv } & 0.5549 & 0.2203 & 0.3653 & 0.1128 & 1 & & & & \\ \text { Banking } & 0.5336 & 0.2719 & 0.4498 & 0.374 & 0.6935 & 1 & & & \\ \text { WP } & 0.4637 & 0.2387 & 0.4395 & 0.3724 & 0.7131 & 0.7082 & 1 & & \\ \text { PROP } & 0.547 & 0.142 & 0.2782 & 0.0192 & 0.6907 & 0.6465 & 0.5394 & 1 & & \\ \text { REG } & 0.5114 & 0.1133 & 0.2802 & 0.112 & 0.686 & 0.6166 & 0.6133 & 0.7947 & 1 & \\ \text { INFMKT } & 0.4629 & 0.1221 & 0.3875 & 0.2779 & 0.5447 & 0.5804 & 0.5393 & 0.6075 & 0.5294 & 1\end{array}$

Note: Trade: trade policy; Fiscal: fiscal policy; Gov_int: government intervention; Mon_pol: monetary policy; For_inv: capital flows and foreign investment; Banking: banking and finance; WP: wages and prices; PROP: property rights; REG: regulation; and INF_MKT: informal market

\section{Table A.2}

Principal component loading matrix for Economic Freedom factors

\section{Component}

\begin{tabular}{|c|c|c|c|c|c|c|c|c|c|c|}
\hline actor & 1 & 2 & 3 & 4 & 5 & 6 & 7 & 8 & 9 & 10 \\
\hline Trade policy & 0.3173 & -0.0304 & 0.1902 & 0.5506 & 0.182 & 0.6822 & -0.2146 & 0.0856 & $5-0.0844$ & -0.0016 \\
\hline iscal burden & 0.1453 & 0.4527 & 0.8229 & -0.1347 & 0.1491 & -0.2153 & 0.0245 & 0.0651 & I -0.0561 & -0.0464 \\
\hline $\begin{array}{l}\text { overnment } \\
\text { nsumption }\end{array}$ & 0.2545 & 0.3719 & -0.2087 & 0.6592 & -0.2696 & -0.417 & 0.2683 & -0.0026 & 0.0164 & -0.0014 \\
\hline Ionetary policy & 0.16 & 0.6411 & -0.3547 & -0.3297 & 0.1732 & 0.3709 & 0.2282 & 0.0794 & 0.2891 & 0.1393 \\
\hline $\begin{array}{l}\text { reign } \\
\text { vestment }\end{array}$ & 0.3753 & -0.175 & 0.1129 & -0.0826 & -0.3349 & -0.0709 & -0.3159 & 0.0664 & 0.7656 & -0.0374 \\
\hline $\begin{array}{l}\text { anking and } \\
\text { nance }\end{array}$ & 0.3823 & 0.0629 & -0.0534 & -0.1741 & -0.1205 & 0.0638 & -0.0823 & -0.8241 & $1-0.2062$ & -0.2641 \\
\hline Wage and policy & 0.3663 & 0.0792 & -0.1186 & -0.2658 & -0.4359 & -0.016 & -0.3226 & 0.3825 & -0.5186 & 0.2551 \\
\hline Property rights & 0.3599 & -0.3411 & 0.1002 & -0.0406 & 0.2089 & -0.0877 & 0.3841 & -0.1672 & 0.0179 & 0.7178 \\
\hline egulation & 0.3574 & -0.2935 & 0.0206 & -0.161 & -0.0323 & 0.0851 & 0.5843 & 0.3246 & $5-0.0826$ & -0.5458 \\
\hline formal market & 0.3308 & -0.0396 & -0.278 & -0.0093 & 0.6932 & -0.3905 & -0.36 & 0.1376 & $5-0.0329$ & -0.1703 \\
\hline & 0.5049 & 0.6434 & 0.7264 & 0.7954 & 0.8476 & 0.8931 & 0.9321 & 0.9616 & 0.9838 & \\
\hline
\end{tabular}


Table A.3

Estimation result with Political Rights and Civil Liberties with translog production function

\begin{tabular}{|c|c|c|c|c|}
\hline & \multicolumn{2}{|c|}{ Translog without regional dummy } & \multicolumn{2}{|c|}{ Translog with EA dummy } \\
\hline & PR & $\mathrm{CL}$ & PR & $\mathrm{CL}$ \\
\hline \multicolumn{5}{|l|}{ Production frontier } \\
\hline Constant & $6.33 * *(1.91)$ & $6.45(1.81)$ & $9.69 * * *(3.19)$ & $11.48(3.77)$ \\
\hline $\mathrm{k}$ & $-0.34(-1.3)$ & $-0.29(-1.13)$ & $-0.64 * *(-2.63)$ & $-0.74(-3.06)$ \\
\hline 1 & $136 * * *(7.08)$ & $1.29 * * *(6.92)$ & $1.41 * * *(8.86)$ & $1.33(8.07)$ \\
\hline k2 & $0.03 * * *(30.1)$ & $0.03 * * *(30.38)$ & $0.03 * * *(30.8)$ & $0.03(29.17)$ \\
\hline 12 & $-0.02(-1.17)$ & $-0.01(-0.93)$ & $-0.03 * *(-2.48)$ & $-0.04 * *(-2.72)$ \\
\hline $\mathrm{kl}$ & $-0.02(-1.26)$ & $-0.02(-1.38)$ & $-0.002(-0.13)$ & $0.005(0.28)$ \\
\hline time & $-0.02 * * *(-4.2)$ & $-0.02 * * *(-4.93)$ & $-0.02 * * *(-4.01)$ & $-0.02 * * *(-5.16)$ \\
\hline \multicolumn{5}{|l|}{ Efficiency effects } \\
\hline Constant & $-30.7 * * *(-21.8)$ & $-33.87 * * *(-18.49)$ & $-32.1 * * *(-20.63)$ & $-35.97 * * *(-18.52)$ \\
\hline COMP1 & $1.89 * * *(10.41)$ & $1.05 * * *(5.65)$ & $1.14 * * *(4.01)$ & $0.23(1.51)$ \\
\hline COMP2 & $3.7 * * *(7.6)$ & $2.45^{* * *}(5.17)$ & $2.1 * * *(4.6)$ & $0.47(1.59)$ \\
\hline PR & $1.2 * *(2.94)$ & - & $2.69^{* * *}(5.1)$ & - \\
\hline CL & - & $3.3 * * *(9.92)$ & & $4.72 * * *(12.67)$ \\
\hline EA dummy & - & - & $-13.49 * * *(-5.16)$ & $-17.15 * * *(-11.8)$ \\
\hline time & $1.7 * * *(10.21)$ & $1.13 * * *(10.23)$ & $1.04 * * *(4.15)$ & $0.69^{* * *}(8.2)$ \\
\hline$\sigma 2$ & $12.72 * * *(12.42)$ & $10.84 * * *(8.7)$ & $12.73^{* * *}(13.35)$ & $10.3^{* * *}(11.02)$ \\
\hline$\gamma$ & $0.99 * * *(3495.8)$ & $0 . .99 * * *(3685.64)$ & $0.99 * * *(3837.9)$ & $0.99 * * *(2688.5)$ \\
\hline Log likelihood & -202.18 & -184.48 & -193.74 & -168.59 \\
\hline Likelihood ratio test & 832.96 & 868.36 & 849.85 & 900.15 \\
\hline
\end{tabular}

Note: T-ratios in parenthesis 
Table A.4

Translog production function with $10 \%$ and $6 \%$ depreciation rates, and with China $(\mathrm{CHN})$ and Cambodia-Vietnam (CBD_VN) dummies

\begin{tabular}{|c|c|c|}
\hline & $10 \%$ depreciation & $6 \%$ depreciation \\
\hline \multicolumn{3}{|l|}{ Production frontier } \\
\hline Constant & $11.11 * * *(3.8)$ & $47.28 * * *(47.51)$ \\
\hline $\mathrm{k}$ & $-0.73 * * *(-3.47)$ & $-2.22 * * *(-27.04)$ \\
\hline 1 & $1.36 * * *(8.02)$ & $-0.72 * *(-3.46)$ \\
\hline $\mathrm{k}^{2}$ & $0.03 * *(30.61)$ & $0.021 * * *(34.8)$ \\
\hline $1^{2}$ & $-0.04 * *(-3.15)$ & $-0.07 * * *(-5.2)$ \\
\hline $\mathrm{kl}$ & $0.004(0.26)$ & $0.12 * *(2.04)$ \\
\hline time & $-0.026 * * *(-3.76)$ & $-0.04 * * *(-68.6)$ \\
\hline \multicolumn{3}{|l|}{ Efficiency effect } \\
\hline Constant & $-33.41 * * *(-28.54)$ & $-10.27 * * *(-12.47)$ \\
\hline COMP1 & $0.92 * * *(7.18)$ & $0.58 * * *(5.24)$ \\
\hline COMP2 & $1.7 * * *(5.73)$ & $2.79 * * *(8.71)$ \\
\hline FHI & $3.59 * * *(14.99)$ & $1.52 * * *(9.95)$ \\
\hline $\mathrm{CHN}$ & $-20.61 * *(-3.27)$ & $-1.91 * * *(-4.09)$ \\
\hline CBD_VN & $-14.81 * * *(-12.53)$ & $-5.19 * * *(-5.9)$ \\
\hline time & $0.87 * * *(9.33)$ & $0.31 * *(3.3)$ \\
\hline$\sigma 2$ & $12.26 * * *(13.26)$ & $3.97 * * *(22)$ \\
\hline$\gamma$ & $0.99 * * *(2966.5)$ & $0.99(0.98 \mathrm{E}+8)$ \\
\hline Log likelihood & -182.29 & -427.82 \\
\hline Likelihood ratio test & 871.4 & 382.57 \\
\hline
\end{tabular}

Note: $t$-ratio in parenthesis 


\section{References}

Abu-Qarn, A.S. and Abu-Bader, S., 2007. Sources of Growth Revisited: Evidence from Selected MENA Countries. World Development 35:5, 752-771.

Adkins, L.C., Moomaw, R.L. and Savvides, A., 2002. Institutions, Freedom and Technical Efficiency. Southern Economic Journal 69:1, 92-108.

Aigner, D.J., Lovell, C. and Schmidt, P., 1977. Formulation and Estimation of Stochastic Frontier Production Function Models. Journal of Econometrics 6, 21-37.

Ali, A., 2003. Institutional Differences as Sources of Growth Differences. Atlantic Economic Journal 31:4, 348-362.

Bardhan, P., 2005. Instittutions matter, but which ones? Economics of Transition 13:3, 499532.

Barro, R.J., 1991. Economic Growth in a Cross Section of Countries. Quarterly Journal of Economics 106:2, 407-443.

Barro, R.J., 1996. Democracy and Growth. Journal of Economic Growth 1:1, 1-27.

Battese, G.E. and Coelli, T.J., 1995. A Model for Technical Inefficiency Effects in a Stochastic Frontier Production Function for Panel Data. Empirical Economics 20, 325 332.

Beach, W.W. and Miles, M.A., 2006. Explaining the Factors of the Index of Economic Freedom, in 2006 Index of Economic Freedom, the Heritage Foundation and the World Street Journal, Washington DC.

Berggren, N., 2003. The Benefits of Economic Freedom: A Survey. The Independent Review $8: 2,193-211$.

Bevan, A., Estrin, S. and Meyer, K., 2004. Foreign Investment Location and Instititonal Development in Transition Economies. International Business Review 13, 43-64.

Bu, Y., 2006. Fixed Capital Stock Depreciation in Developing Countries: Some Evidence from Firm Level Data. Journal of Development Studies 42:5, 881-901.

Blanchard, O. and Kremer, M., 1997. Disorganization. The Quarterly Journal of Economics 112:4, 1091-1126.

Campos, N.F. and Coricelli, F., 2002. Growth in Transition: What We Know, What We Don't, and What We Should. Journal of Economic Literature 40:3, 793-836. 
Carlsson, F. and Lundstrom, S., 2002. Economic Freedom and Growth: Decomposing the effects. Public Choice 112, 335-344.

Coelli, T.J., 1996. A guide to Frontier 4.1: A computer program for stochastic production and cost function estimation. Centre for Efficiency and Productivity Analysis, University of New England, Working Paper 96/07.

Dawson, J., 1998. Institutions, Investment and Growth: New Cross-Country and Panel Data Evidence”. Economic Enquiry 36, 603-619.

Duffy, J. and Papageorgiou, C., 2000. A Cross-Country Empirical Investigation of the Aggregate Production Function Specification. Journal of Economic Growth 5, 87-120.

Dunteman, G.H., 1989. Principal Components Analysis. Sage University Paper Series on Quantitative Applications for Social Sciences, No. 07-069. Newbury Park, CA: Sage

Easterly, W. and Rebelo, S., 1993. Fiscal Policy and Economic Growth. An Empirical Investigation. Journal of Monetary Economics 32, 417-458.

Gwartney, J. D., Lawson, R. A., and Holcombe, R. G, 1999. Economic Freedom and the Environment for Economic Growth. Journal of Institutional and Theoretical Economics 155:4, 643-63.

Heckelman, J.C. and Stroup, M.D., 2005. A Comparison of Aggregation Methods for Measures of Economic Freedom. European Journal of Political Economy 21, 953-966.

Kaufmann, D., Kraay, A. and Zoido-Lobaton, P., 1999. Governance Matters. World Bank Working Paper No. 2196.

Kaufmann, D., Kraay, A. and Mastruzzi, M., 2005. Governance Matters IV: Governance Indicators for 1996-2004. World Bank Policy Research Working Paper No. 4280.

Knack, S. and Keefer, P., 1995. Institutions and Economic Performance: Cross-Country Tests Using Alternative Institutional Measures. Economics and Politics 7:3, 207-227.

Kneller, R. and Stevens, P.A., 2003. The specification of the aggregate production function in the presence of inefficiency. Economic Letters 81, 223-226.

Mauro, P., 1995. Corruption and Growth. Quarterly Journal of Economics 110:3, 681-712.

Meeusen, W. and Broeck,J.V.D, 1977. Efficiency Estimation from Cobb-Douglas Production Functions with Comosed Error. International Economic Review 18, 435-444.

Miles, M., Holmes, K. and O’Grady, M.A., 2006. 2006 Index of Economic Freedom, The Heritage Foundation, Washington DC and World Street Journal, New York. 
Minier, J. A., 1998. Democracy and Growth. Journal of Economic Growth 3, 241-266.

Méon, P. and Weill, L., 2005. Does better governance foster efficiency? An aggregate frontier analysis. Economics of Governance 6, 75-90.

Moroney, J.R. and Lovell, C. A. K., 1997. The Relative Efficiencies of Market and Planned Economies. Southern Economic Journal 63:4, 1084-1093

Murrell, P., 2003. The relative levels and character of institutional development in transition economies, in Political Economy of Transition and Development: Institutions, Politics and Policy, ed. Nauro Campos and Jan Fidrmuc, Kluwer, Boston, Dordrect and London.

North, D.C., 1990. Institutions, Institutional Change and Economic Performance. Cambridge: Cambridge University Press.

Olson, M. Jr., Sarna, N. and Swamy, A. V., 2000. Governance and Growth: A simple hypothesis explaining cross-country differences in productivity growth. Public Choice $102,341-364$.

Pritchett, L., 2000. The Tyranny of Concepts: CUDIE (Cumulated, Depreciated, Investment Effort) Is Not Capital. Journal of Economic Growth 5, 361-384.

Rodrik, D., 2000. Institutions for High-Quality Growth: What They Are and How to Acquire Them. Studies in Comparative International Development 35:3, 3-31.

Sandholtz, W. and Koetzle, W., 2000. Accounting for Corruption: Economic Structure, Democracy and Trade. International Studies Quarterly 44, 31-50.

Sung, H.. 2004. Democracy and Political Corruption: A Cross Country Comparison. Crime, Law and Social Change 41, 179-194.

Svejnar, J., 2002. Transition Economies: Performance and Challenges. Journal of Economic Perspectives 16:1, 3-28.

Tavares, J. and Wacziarg, R., 2001. How Democracy Affects Growth. European Economic Review 45, 1341-1378.

Treisman, D., 2000. The causes of corruption: A cross-national study. Journal of Public Economics 76, 399-457. 